\title{
Sob o Rigor da Lei: Os Africanos e a Legislação Baiana no Século XIX.
}

\author{
Luiama da Crz Bito
}

\begin{abstract}
Resumo: A legislação produzida no Brasil durante o século XIX, sobretudo o Código Criminal do Império do Brasil, procurou atender demandas sociais no sentido de impedir e punir com rigor os atos de resistência negra que ameaçassem a estrutura social escravista. Associado ao debate nacional e as medidas parlamentares para prevenir e castigar tais ações consideradas criminosas, além de suspeitas e ameaçadoras, ocorriam os debates parlamentares sobre segurança pública na província da Bahia. As freqüentes insurreições promovidas por africanos e afro-descendentes tornava mais específicas as necessidades dos presidentes de província e chefes de polícia baianos, provocando, às vezes, distorções da lei ou até mesmo o não cumprimento dela. Nosso interesse é investigar como a legislação provincial na Bahia manifestava os objetivos de controle social sobre a população africana na primeira metade do século XIX, uma vez que os africanos eram considerados "mais perigosos" a ponto de receberem uma legislação particular, que os colocava num patamar destino daquele ocupado pelos negros nascidos no Brasil.
\end{abstract}

Palavras-chave: escravidão, africanos, Bahia, legislação, império.

Abstract: D uring the 19th century, Brazilian legislation, specifically the Criminal Code of the Brazilian Empire, sought to meet societal demands by rigorously controlling and punishing the actions of slaves that threatened the slavocratic social structure. The national debate and parliamentary measures to contain and punish the actions of criminal slaves, which included attitudes considered suspicious and threatening, were associated with debates about public safety in the province of Bahia. After the Revolt of the Malês, which occurred in Salvador in 1835, the repression of slave resistance became a priority for provincial presidents and police chiefs, provoking, at times, legal distortions or even violations of the law. In this article, we investigate how provincial legislation manifested social control over the African population in Bahia in the first half of the 19th century in as much as Africans roused "white fear" in Bahian slavocratic society.

Keywords: slavery, Africans, Bahia, legislation, empire.

Este trabalho tem como proposta fazer uma análise sobre as repercussões políticas e sociais da presença africana na cidade de Salvador na primeira metade do século XIX. Para tanto, faremos uso dos debates políticos e parlamentares sobre a "ameaça" africana nesta cidade.

A legislação Nacional, através do código criminal do Império do Brasil, era mais genérica ao voltar suas atenções para os crimes cometidos por scravos- e mesmo libertos fossem eles africanos ou crioulos. Já a legislação local, sobretudo durante a década de 30 do século XIX, dirigia especial atenção aos africanos (pretos), pois acreditava-se que estes indivíduos eram mais "perigosos". Esta crença na carência de um conjunto de leis específicas para os africanos refletia uma espécie de "demanda" ou necessidade local.

Investigaremos como a presença dos africanos na cidade de Salvador repercutiu na legislação produzida pelo Império e pelos deputados baianos. Para isso, usaremos como material de pesquisa as atas da Assembléia Provincial Legislativa e as leis produzidas nesta instituição, relatórios provinciais e jornais da época. Acreditamos que seja possível, através desta documentação, entender a lógica que a elite política baiana utilizava para categorizar estes africanos como sujeitos que traziam mais perigo para a sociedade que os crioulos.

\footnotetext{
${ }^{1}$ Mestranda em História Social da Cultura da Universidade Estadual de Campinas - UNICAMP e Bolsista da Fundação de Amparo à Pesquisa do Estado de São Paulo - FAPESP. Email: cruzluciana@ yahoo.com.br
} 
Seria importante entender 0 impacto desta presença numérica africana na cidade de Salvador no século XIX. A demanda de braços para o trabalho nas lavouras açucareiras do Recôncavo baiano era suprida pelo crescente tráfico. Isto fez com que os africanos compusessem a parcela da população que mais cresceu neste período. Vale lembrar 0 pouco tempo de vida dos africanos escravizados, o que criava uma demanda de mão de obra constante que era suprida pelo tráfico.

O historiador João José Reis fez uma estimativa do número de africanos na Bahia na década de 1830. Segundo ele, entre os anos de 1821 e 1830, o número de fricanos importados para a Bahia foi de 71.600, e depois da lei de proibição do tráfico em 1831, este número caiu para 32.500 africanos. Em 1835, os cativos compunham $42 \%$ da população local. Segundo dados populacionais estimados por este historiador, a maioria destes cativos era composta por africanos (62\%) que entravam na cidade mesmo após a lei que proibia 0 tráfico (REIS, 2003, p.24).

O crescimento do número de cativos nas zonas açucareiras da Bahia, inclusive na capital (Salvador), causou um clima de pavor social quanto à possibilidade de que viesse a se organizar no Brasil, sobretudo no recôncavo baiano, uma revolta de escravos na mesma proporção da ocorrida no Haiti. O medo do "haitianismo", junto ao fato de a primeira metade do século XIX ser marcada por diversas revoltas na Bahia, suscitou o debate a respeito da questão da segurança naquele período ${ }^{2}$.

Historiadores apontam uma ligação entre densidade populacional negra nos grandes centros urbanos e a ocorrência freqüente de crimes e revoltas escravas. Cidades com grande população escrava se tornavam um desafio para o controle policial. A necessidade de um aparato legal para controlar o contingente cativo se dava por muitas razões, visto que se acreditava que determinadas ações escravas ameaçavam o status qua Este sentimento de insegurança fez com que tais aspectos ameaçadores supostamente inerentes aos cativos, e até mesmo africanos livres e libertos, fossem discutidos por parlamentares, legisladores e proprietários de escravos.

A maioria populacional africana entre os cativos de Salvador na primeira metade do século XIX era composta, sobretudo, por haussás e nagôs, e foram eles que imprimiram presença maciça nas revoltas escravas que ocorreram na Bahia neste período. Reis também

\footnotetext{
2 Sobre a revolta do Haiti e suas implicações no Recôncavo Baiano ver: REIS, João José. "Nós achamos em campo a tratar da liberdade": Resistência negra no Brasil oitocentista. In: MOTA, Carlos Guilherme (org.). ViagemInơmdła A experiência brasileira (1500-200) formação: histórias. São Paulo: Ed. SENAC, 2000, pp. 243-263.
} 
afirma que este número de africanos, embora formado por grupos étnicos diversos, possibilitou a criação de laços de solidariedade intra-étnicos, e até mesmo entre africanos e crioulos, fossem eles escravos ou libertos (REIS, 1992, pp.100-126).

A onda de revoltas escravas na Bahia, durante a primeira metade do século XIX, fez com que os senhores de escravos e políticos baianos começassem a perceber nos africanos, sobretudo quando libertos, uma ameaça que merecia atenção distinta. Se os escravos, por serem propriedade, seriam controlados com medidas apropriadas ao seu status jurídico, 0 que fazer com os libertos africanos, que teoricamente, tinham liberdade de transitar por onde quisessem? Por que os libertos africanos mereciam mais atenção que os libertos crioulos?

Estas questões foram discutidas pelo Conselho Geral da Província da Bahia no ano de 1829 com o objetivo de elaborar uma lei que atendesse a estas questões. Este trabalho só seria conclú́do em 1830, com a aprovação do decreto de 14 de dezembro daquele ano. A questão do controle dos escravos e o debate sobre a especificidade dos africanos libertos foi assunto principal das pautas das sessões desde o mês de janeiro do ano de 1829. Era consenso entre os deputados a necessidade de uma cédula que identificaria os escravos, mas suas opiniões divergiam a respeito de quem deveria ser responsabilizado quando 0 escravo fosse encontrado sem este documento obrigatório. Em 14 de janeiro daquele ano, o Sr. Uzel, membro do conselho geral, considerava inexequível e inaplicável uma pena destinada aos senhores dos escravos capturados sem a cédula de identificação. Foi aceita a não criminalização dos proprietários de escravos encontrados sem a cédula. Além disso, foi garantido que o castigo do escravo fosse aplicado no âmbito privado, pois este deveria ser devolvido ao seu senhor para que fosse castigado "moderadamente" 3 .

Na seção de 17 de janeiro do mesmo ano, a pauta do debate se destinava aos africanos forros ${ }^{4}$. A preocupação dos deputados baianos era sobre como controlar o trânsito destes africanos e o contato deles com os escravos, uma vez que eram vistos como uma influência perigosa para aqueles que ainda viviam no cativeiro. Decidiu-se que os africanos também deveriam portar um passaporte contendo informações que facilitassem sua identificação e que também informasse sobre sua periculosidade. Questões concernentes às implicações do uso deste passaporte no andamento do comércio e demais atividades desenvolvidas pelos africanos foram apontadas nesta sessão. Obrigar o uso do passaporte para os africanos forros encarregados de transportar mercadorias entre Salvador e as cidades do recôncavo poderia prejudicar o comércio, o que fez com que as opiniões se

${ }^{3}$ APE B, Ata do Conselho Geral da Província da Bahia. Livro 197. Sessão Legislativa.

${ }^{4}$ APE B, Ata do Conselho Geral da Província da Bahia. Livro 197. Sessão Legislativa. 
dividissem a este respeito. O deputado Pinheiro propôs que ficasem isentos deste passaporte os africanos forros de ambos os sexos que fossem empregados em, diariamente, transportar gêneros de primeira necessidade. Entretanto, o deputado Uzel reforçou a necessidade do passaporte propondo uma medida que obrigasse os africanos forros, de ambos os sexos de possuí-lo, e que fosse concedido pela autoridade local, determinando 0 tempo que o africano ou africana estaria longe de sua residência. 0 Barão de Itaparica, também membro do conselho, refirmando a inaplicabilidade da lei, sugeriu que esta emenda fosse suspensa.

Também existiram propostas para que o passaporte só fosse obrigatório para os africanos e africanas que estivessem em trânsito por mais de três dias, mas não houve consenso. A questão teve que ser posta em votação e decidiu-se que o artigo que obrigava 0 uso do passaporte não seria suprimido. Por fim, foi aceita a proposta do deputado que sugeriu a isenção para aqueles africanos que transportassem gêneros de primeira necessidade. Podemos inferir que o que estava em questão era a manutenção do comércio de gêneros alimentícios, que ligava a capital da província, Salvador, à região do recôncavo baiano. 0 transporte destes produtos era controlado por africanos, muitos deles forros. A interferência demasiada neste comércio, naquele momento, poderia significar pôr em risco o suprimento de alimentos, cas os africanos resolvessem se manifestar contra a interferência do govemo no andamento do seu trabalho.

Na sessão do dia 21 do mesmo ano foi revisado o texto das leis e foi dada ênfase à necessidade de frisar que estas leis eram válidas para os "pretos forros africanos", e assim deveria estar escrito no texto legal a quem esta determinação se dirigia. Em seguida, debateu-se como seriam punidos aqueles e aquelas que não portassem 0 tal passaporte. Primeiramente o deputado Calmom, propôs que os africanos ficassem presos por 30 dias, e os escravos fossem açoitados no pelourinho. Imediatamente o Barão de Itaparica retrucou, propondo que a pena dos africanos fosse reduzida para oito dias, mas não foi apoiado. 0 secretário do conselho também tentou reduzir o tempo de prisão dos africanos forros para 24 horas e os escravos, 20 açoites, mas isto também foi negado. Tratou-se também de discutir quais penas seriam aplicadas a escravos que dançassem com escravos de outros senhores em seus dias de folga, bem como forros que dançassem com escravos. Logo 0 mesmo deputado que levantou o debate para punição das "danças", o Sr. Calmon, retirou sua proposta por considerá-la desnecessária ${ }^{5}$.

${ }^{5}$ APE B, Ata do Conselho Geral da Província da Bahia. Livro 197. Sessão Legislativa. 
As determinações do ano de 1829 mostravam os dilemas dos legisladores baianos que ainda se encontravam em questões concernentes à mediação entre questões públicas e privadas, como o castigo de escravos. A necessidade de controlar o trânsito de cativos e africanos forros de ambos os sexos esbarrava na possibilidade de atravancar o comércio local, já que estes indivíduos eram responsáveis pelo transporte, setor que interessava inclusive à elite baiana. Outro fator importante é que, já neste período, os africanos eram vistos como sujeitos que deveriam continuar sob o controle do Estado ainda depois de libertos. 0 contato deles com os escravos, seja em momentos de lazer, como na dança, seja nas viagens para o recôncavo, quanto envolvidos no transporte de mercadorias, eram vistos como momentos nos quais poderiam ser criadas oportunidades para possíveis articulações que desencadeassem revoltas.

Os debates do ano de 1829 teriam um desfecho com o decreto de 14 de dezembro de $1830^{6}$ que visava estabelecer as medidas policiais a serem aplicadas para controlar 0 trânsito de escravos e africanos libertos. 0 decreto também era mais específico a respeito de quais informações deveriam constar nas cédulas dos escravos e nos passaportes dos africanos libertos, bem como as punições previstas para os que não potassem este documento e as condições impostas ao trânsito de ambos. No su texto também são reveladas as preocupações daqueles que o escreveram sobre como os africanos, em contato com os escravos, constituíam-se numa grave ameaça.

No primeiro artigo do Decreto, a preocupação são os escravos Estes eram obrigados a portar cédulas de identificação quando se ausentassem da cidade ou povoado em que viviam. As cédulas deveiam ser expedidas pelo seu ænhor, bem como administradores ou feitores, œntendo informações sobre o nome do escravizado, sua naturalidade, seus sinais mais característicos e tempo que deveria durar esta cédula. No artigo segundo, estabelecia se que, como pena, o cativo que infligisse a lei deveria ser entregue ao seu senhor para ser castigado "moderadamente". Vêse que quanto aos escravos pouco foi modificado em relação ao que foi discutidb desde 1829. As preocupações com possíveis fugas eram solucionadas pelas cédulas, que facilitariam a identificação e busca do cativo que porventura fugisse. É importante lembrar que tais "sinais característicos" poderiam ser comparados com aqueles encontrados nos jomais, na sessão de escravos fugitivos. Sobre os castigos, vêse que as leis respeitaram o direito dos senhores de castigar seus escravos como quisessem, pois interferir em tal relação privada de propriedade e dominação poderia causar a antipatia de determinados setores da sociedade.

${ }^{6}$ Coleção de Leis e Decretos do Império do Brasil. Disponível no site da Câmara dos Deputados. Disponível em www.camara.gov.br. 
Finalmente, os artigos 3 e 4 tratam dos africanos forros. No terceiro, as mesmas preocupações em relação aos escravos aparecem. Segundo este, os "pretos e pretas forros africanos" não poderiam deixar seu domicílio sem levar consigo um passaporte expedido pelo juiz de paz ou juiz criminal. Este passaporte só seria concedido com a presença de três testemunhas que abonassem a conduta do africano ou africana que o solicitava. Tal como nas cédulas dos escravos, neste documento deveria haver informações contendo dados como nome, sinais característicos, local de destino e tempo que deveria valer o passaporte. No artigo seguinte é estabelecida a pena de oito dias de prisão para aqueles que fossem encontrados sem este documento, e no caso de reincidências a pena era dobrada.

Alguns aspectos interessantes chamam atenção nos artigos que se referem aos africanos. É preciso enfatizar que, em se tratando de forros somente os africanos e africanas eram obrigados a portar o passaporte, os forros crioulos eram isentos desta obrigação. Como explicação para este fato, podemos utilizar um trecho citado neste mesmo artigo, que diz o seguinte: "...há toda presunção e suspeita que tais pretos são os incitadores e provocadores de tumultos e comoções que se tem abalançado os que existem na escravidão." Sendo assim, os africanos eram considerados mais perigosos pois acreditava-se que eles continuavam envolvidos em revoltas e demais atos de resistência à escravidão, mesmo quando livres do cativeiro.

Ainda sobre a obrigatoriedade do uso do passaporte pelos aficanos e africanas forros, o fato destes documentos serem expedidos pelos juízes de paz ou pelo juiz criminal diz muito sobre o estigma de suspeição que acompanhava estes africanos, mesmo quando não mais escravizados. 0 status jurídico de forro, almejado por muitos, em diversos momentos pouco dizia numa sociedade escravista, que via o africano ou africana, ainda que liberto, como sujeitos que faziam parte de uma parcela da sociedade de condição sócioracial inferior. As três testemunhas que, na aquisição do passaporte, eram obrigatórias para atestar sua boa conduta, colocavam os africanos numa condição de subalternidade e vigilância em relação àqueles que acompanhavam suas ações cotidianas.

No contexto de debates e preoaupações sobre rebeliões e crimes de escravos, foi elaborado o Código Criminal do Império do Brasil, em 1830. Este código veio responder a questões sobre o que era crime em termos legais. Além de definir o que era crime, o código criminal do Império especificava quais penas deveriam ser aplicadas aos criminosos, escravos ou não, e quais atitudes passariam a ser tipificadas como crime ${ }^{7}$.

7 Código Criminal do Impéio do Brasil Theorica e praticamente anotado pelo bacharel Francisco Luiz. Maceió: Tipografia de T. de Menezes, 1885. 
Desde a Constituição de 1824, a legislação brasileira passou a distinguir as penas criminais destinadas a pessoas livres daquelas destinadas aos escravos (HOLLOWAY, 1997, p.68 e RIBEIRO, 2005, p.57). Isto se aprimorou com o Código Criminal de 1830, que especificava o tipo de pena que sofreriam os indivíduos de acordo com seu status jurídico e tipo de crime que haviam cometido, constituindo-se numa hierarquia da gravidade dos delitos. 0 olhar que os legisladores dispensavam a respeito de um mesmo ato de transgressão da lei, diferenciava-se de acordo com aquele que o cometera. Ainda neste código, os escravos eram definidos de forma genérica, não havendo distinção entre cativos crioulos e africanos, diferente das leis baianas que, em boa parte das vezes, fazia esta diferenciação.

Um bom exemplo do que acabamos de afirmar é a diferença existente na legislação criminal a respeito das manifestações, armadas ou não, contra a ordem social e política estabelecida. Quando estes motins eram liderados por escravos, o código classificava-os como insureçãa já quando se tratavam de sublevações protagonizadas por não-escravos, 0 código enquadrava-as no crime de rebdião ou conspiração, ou seja, um crime poĺtico. Entretanto, 0 artigo 114, quando se referia à participação de pessoas livres como líderes de uma insurreição, a pena prescrita a eles era a mesma aplicada aos escravos ${ }^{8}$. Acredito que a pena para os livres referidos no artigo 114 se destinava, sobretudo, aos libertos.

Associado ao debate nacional e as medidas parlamentares para conter e punir a ação dos escravos criminosos, ou aqueles considerados suspeitos e ameaçadores, aconteciam os debates sobre segurança pública nas províncias brasileiras. No âmbito local, a resistência escrava parecia tornar mais especificas as necessidades de presidentes de província e chefes de polícia, o que provocaria, às vezes, distorções da lei ou até mesmo o não cumprimento delas. Sendo assim, nossa preocupação é investigar como os acontecimentos locás acompanhavam (ou não) a legislação imperial.

${ }^{8}$ Códgo Cinimal do Impéio do Brasil. Theorica e praticamente anotado pelo bacharel Francisco Luiz. Maceió: Tipografia de T. de Menezes, 1885. Ver os artigos 117, 110 e113 e 114. 
Em janeiro de 1835, um novo acontecimento fortaleceu o debate em torno da necessidade de maior rigidez nas leis concementes aos crimes de escravos. Aproveitando o envolvimento dos senhores com as festividades de Nosso Senhor do Bonfim, africanos escravos e libertos islamizados se insurgiram na Bahia. O principal objetivo do levante era tomar a cidade de Salvador e se articular com cativos do recôncavo baiano a fim de matar os brancos e escravizar os mulatos. Estourava assim o levante dos malês (REIS, 2003).

A sensação de insegurança que seguiu à insurreição malê criou um ambiente "antiafricano" que envolveu Salvador e o Recôncavo baiano. A rejèção aos africanos se manifestou nas agressões físicas que eles sofreram neste período, chamando atenção, até mesmo das autoridades policiais. Em 28 de janeiro de 1835, o enérgico chefe de polícia, Francisco de Souza Martins, enviou um documento para o presidente da província da Bahia afirmando estar surpreendido com a onduta dos soldados que ele mømo considerou "estranha". Segundo ele, era comum que naqueles dias, pretos pacíficos fossem vítimas de agressões físicas e assassinatos cometidos nas ruas da cidade de Salvador. Segundo Martins, suas preocupações giravam em torno da possibilidade de que a onda de violência, até então dirigida unicamente aos pretos africanos, se estendesse contra "outra espécie de gente". ${ }^{9}$

O debate nacional já em curso acerca da gestão do controle social da população negra no Brasil objetivava pensar uma forma de reprimir a rebeldia africana que não saísse do controle do Estado. Para que este objetivo fosse atingido eram necessárias medidas legais que suspendessem até mesmo direitos constitucionais, como 0 artigo 179 da constituição do Império, que veremos adiante. No dia quatro de março de 1835, o Presidente da Província da Bahia escreveu ao Imperador para explicar os fatos ocorridos e para justificar as medidas de segurança que tinha implementado na capital baiana:

Datado de 14 de fevereiro passado, no qual vem se expondo V. Ex. o terror que tem se apoderado da população dessa cidade em conseqüência da revolta de africanos na noite de 24 para 25 de janeiro último, exige do Governo Imperial algumas medidas extraordinárias que, sem ofensa das leis, dos tratados e dos princípios gerais do direito das gentes, se podem e devem quanto antes tomar para dar maior segurança à província, e sossegar os espíritos receosos da impunidade dos mesmos africanos, visto que tem sido cometido o crime nas trevas da noite, não era fácil achar contra todos os criminosos provas bastantes para a condenação ${ }^{10}$.

${ }^{9}$ APE B. Seção Colonial e Provincial. Maço 2949.

10 Coleção das Leis e D ecretos do ano de 1835. Disponível em www.camara.gov.br. 
Dentre as muitas idéias que foram debatidas como medidas que servissem como solução para a ameaça trazida pelos africanos, o Presidente da Província, Manuel Alves Branco, acreditava que deveria se evitar que estes africanos saíssem da província para qualquer outra parte do império. Certamente, estava se referindo à possibilidade de que estes africanos fossem vendidos para outras províncias, como forma encontrada por senhores de escravos e traficates para não ter prejuízos com a perda da sua "propriedade" para a justiça, por causa das deportações. Como a entrada dos africanos na cidade de Salvador era repimida como medida de segurança o presidente da província cobrava do Império um rígido controle para a aplicação da lei que proibia 0 tráfico de africanos no Brasil desde 1831.

Como se pode perceber, as especificidades das medidas aplicadas pelo presidente da Província da Bahia nem sempre estavam contempladas nos códigos e nas leis imperiais. Enquanto o código criminal do Império tipificava os crimes cometidos por escravos, o presidente da província sentia a necessidade de especificar nas leis baianas, os africanos como elementos mais perigosos. A preocupação dirigida aos africanos não especificava grupos étnicos, embora os senhores de escravos e a justiça baiana soubessem que a religião muçulmana era um traço comum entre os envolvidos no levante.

Embora a quantidade de africanos na cidade de Salvador tenha sido entendida como um dos motivos da insurreição, esta preocupação já era antenior à revolta de 1835. Em 1833, o então Ministro da Justiça Aureliano de Souza e Oliveira Coutinho denunciou no seu relatório anual a continuidade do tráfico com a conivência de autoridades locais ${ }^{11}$. Já era presente também no relatónio do presidente da Província da Bahia do ano de 1831, a cobrança do cumprimento da que extinguia o tráfico de escravos. Isto pode ser entendido como uma denúncia de que este tipo de comércio ainda ocorria com frequiência, ainda que proibido. O tráfico de africams contrariava as medidas implementadas que visam apresentar soluções na área de segurança e além de pôr em risco os projetos de civilização vigentes em todo país. Veremos mais adiante como as leis da Assembléia Legislativa Provincial reforçaram a necessidade de deportar os africanos libertos e controlar a entrada de escravos pelo tráfico ${ }^{12}$.

Somos levados a crer que era omum a todos a crença na responsabilidade dos africanos a respeito da revolta e foi sobre eles que recaiu uma forte reação social, jurídica e

${ }^{11}$ www.crl.edu / ver a seção de ministerial reports de 1833.

12 www.crl.edu / ver a seção de ministeial reparts de 1831. 
policial. Segundo João José Reis, os crioulos não participaram do levante e fizeram questão de se distinguir dos africanos, reafirmando seu grau de incorporação ao modo de vida no Brasil, sobretudo nas práticas religiosas e culturais (REIS, 2003, pp.319-320). Diferente da Bahia, a revolta dos escravos de 1833 ocorrida em Carrancas, na Província de Minas Gerais, contava com a participação de escravos crioulos. Segundo o historiador Marcos Ferreira de Andrade, a revolta ocorrida em Carrancas fugia do padrão das que ocorreram em outras regiões do Império, destacando-se pela articulação de africanos e crioulos na revolta (ANDRADE, 1996).

Na Bahia não foi assim. Todos os réus julgados no levante dos malês eram africanos, escravos ou libertos. Após o levante, a resposta ocorreu tanto nas duras penas que os africanos acusados sofreram, quanto nas leis que foram produzidas após o levante, fazendo aumentar o controle sobre os africanos escravos e dificultando a vida dos africanos libertos.

No dia 28 de Março de 1835, dois meses depois do levante dos malês, a Assembléia Legislativa da Bahia suspendia por trinta dias o artigo 179 da Constituição do Império. Este artigo da Constituição garantia a inviolabilidade dos direitos civis e políticos dos "cidadãos brasileiros". 0 inciso IV deste artigo afirmava que "todo cidadão tem em sua casa um asilo inviolável" ${ }^{13}$. Com a suspensão do artigo 179 as residências poderiam ser invadidas pela polícia sob a justificativa de "se darem buscas em todas as casas a fim de prevenir-se a insurreição de africanos" ${ }^{14}$. Sabendo que os envolvidos no levante eram africanos, podemos imaginar a repressão policial que se abateu sobre os domicílios de africanos libertos e escravos, uma vez que naquele momento era generalizada a suspeição de que qualquer africano pudesse estar envolvido no levante.

No dia 13 de maio de 1835 mais uma lei, conhecida como Lei número Nove, foi posta em vigor para "conter" a ameaça africana na Bahia. Os seus 23 artigos mostram que a principal preocupação de alguns políticos baianos era promover a deportação dos africanos libertos, controlar com rigidez o trânsito dos africanos escravos pelas cidades e barrar a entrada de novos africanos peb tráfico, reexportando-os para a África. Neste texto daremos ênfase a alguns dos artigos presentes na lei número nove e analisaremos qual 0 impacto desta lei na vida dos africanos e africanas que viviam na Bahia em 1835.

${ }^{13}$ ConstitiçãodoImpéiodbBrasil de1824 Artigo 179, inciso 4. A constituição pode ser encontrada no site de Leis Imperiais da Câmara dos Deputados www.camara.gov.br

14 APEBA. A ssembléia Provincial da Bahia, Atas das Sessões, livro 206, Sessão de 28 de Março de 1835. 
0 artigo primeiro da lei número nove tratava dos africanos libertos especificamente ${ }^{15}$. A eles foi enfaticamente atribuída a categoria de suspeitos e estabelecida a ordem de prisão dos que, aos olhos das autoriddes provinciais, inspirassem qualquer tipo de "desconfiança". Como solução para os envolvidos na insurreição, ou até suspeitos de envolvimento, o recurso a ser empregado era a deportação. Os acusados de envolvimento eram identificados através dos passaportes cujas orientações aparecem na Lei de 14 de dezembro de 1830.

O governo fica autorizado a fazer sair para fora da Província quanto antes, e ainda mesmo à custa da fazenda pública, quaisquer africano fôrro de um ou outro sexo, que se fizerem suspeitos de promover de algum modo a insurreição de escravos e poderá ordenar que sejam recolhidos à prisão até que sejam reexportados.

Este artigo, que inicia as medidas legais de repressão aos africanos, pode ter sido 0 que mais atingiu a vida dos africanos libertos. Nas sessões da assembléia provincial da Bahia foram debatidas diversas propostas de leis destinadas aos africanos, tal como 0 registro obrigatório por meio de matriculas, a proibição de possuir bens e o pagamento de diversas taxas para exercer atividades comerciais ${ }^{16}$. Porém, 0 artigo primeiro da lei número Nove provocou diversas reações por parte dos africanos libertos que viviam na Bahia, devido ao impacto causado em suas vidas. Recorrer à justiça foi uma das ferramentas utilizadas por muitos deles na tentativa de fazer suas reivindicações por direitos através das petições que muitos enviaram à assembléia provincial.

Uma destas petições era de um africano gêge liberto chamado Filipe Francisco Sen $a^{17}$. Na petição entregue pelo seu procurador, o africano Filipe, maior de 50 anos, afirmava que estava na Costa da África exercendo atividade de administrador da feitoria de Joaquim José Duarte em 28 de fevereiro de 1835. Com a implementação da lei número Nove, e por causa do artigo primeiro, foi impossibilitado de voltar à Bahia, onde morava juntamente com sua família. Este liberto usou de todos os argumentos para convencer a justiça de que, posto fosse africano, não era suspeito, e pelo contrário, era leal ao Império do Brasil, alegando sua fidelidade à pátria, visto que havia lutado pela independência, era defensor da constituição e adotou a doutrina cristã. Sendo assim, alegando que a lei de deportação não se aplicava a ele, apelou para o senso de justiça das autoridades baianas:

\footnotetext{
${ }^{15}$ APEBA. A ssembléia Provincial da Bahia 05 de maio de 1835. Lei n.09. Série: Registros de Leis, Livro 1. ${ }^{16}$ APEBA. A ta das Sessões da Assembléia Provincial Legislativa do ano de 1835. Livro 206.

${ }^{17}$ APEBA. Seção legislativa, livro número 1928, petições de 1837.
} 


\begin{abstract}
...fazendo suas funções de soldado e súdito tão bem, nesta qualidade de Sua Magestade Imperial e logo como achando-se o suplicante neste estado, poderia ser compreendido na mesmíssima lei que, em globo, fora disposta para aqueles que não gozam do foro de cidadão brasileiro, como é o suplicante, e reexportados por inimigos do governo[?] Parece a toda prova injustiça que se fará ao suplicante.
\end{abstract}

Filipe, que certamente obteve cidadania brasileira, ainda afirmava que só receberia 0 pagamento do seu trabalho caso conseguisse voltar para à Bahia. Contudo, seus fortes argumentos não foram suficientes para convencer a assemblêa da sua idoneidade e fidelidade ao governo. 0 seu requerimento chegou à comissão de petições em 16 de março e 1837, e obteve resultado negativo em 23 de abril de 1838. O u seja, este africano liberto, que optou pela legalidade para reivindicar seus direitos, apelando por justiça, esperou quase um ano para receber uma resposta negativa ao seu pedido de retornar à Bahia legalmente.

O tráfico de africanos foi questão muito debatida nas seções da assembléia provincial legislativa da Bahia, fundamentando a defesa de uma forte vigilância que garantisse a obediência à lei anti-tráfico de 1831. Isto ocorreu pelo consenso de que a existência de revoltas escravas e os crimes estavam diretamente ligados à quantidade de africanos na província, e embora este discurso já existisse anteriormente, em 1835 esta crença ficou mais forte. A sessão da assembléia de 06 de março de 1835 anunci@ o rumo dos posicionamentos sobre a necessidade de medidas legais mais duras para reprimir o tráfico de africanos ${ }^{18}$. Nesta data, o deputado Calmon exigia informações sobre a quantidade de africanos que haviam sido despachados para fora da província depois da insurreição malê. Certamente o deputado estava tentando observar se as leis estavam sendo obedecidas.

O discurso em defesa do cumprimento da lei de 1831 trouxe até mesmo denúncias da continuidade do tráfico ocorrida por causa da conivência dajustiça. Na mesma sessão do dia 06 de março, o deputado Espínola se manifestou exigindo explicações que justificassem o fato de africanos apreendidos, em 1834, na barca Maria da Glória, ainda não terem sido deportados. Mas a fala que melhor traduzia esta preocupação com a presença africana crescente cada vez mais pelo tráfico foi aquela feita no final da sessão pelo deputado Calmon: "Requiro que as comissões de pdicia proinial e fazenda propurham medidas condurentes a reprimir a impatação de afrimos nesta proúnia e expurgre esta adade do excsso do número de escravos..".

As preocupações postas pelo deputado culminaram no artigo quarto da lei número nove. O referido artigo dizia que os africanos e africanas desembarcados no Brasil após a lei de 1831, tão logo fosse constatada a irregularidade da sua presença no país, deveriam ser

${ }^{18}$ APEBA. Ata das sessões da Assembléia Provincial Legislativa de 1835, livro 206. 
imediatamente reexportados, da mesma forma que os libertos "nesmo não suspitos". As embarcações também passavam a ser fiscalizadas pelo governo, obrigando que elas levassem consigo uma quantidade determinada de africanos toda vez que saíssem dos portos baianos. Embora fosse evidente a recusa de se trazer escravos da África para 0 Brasil, a lei não especifica se seria ilegal trazer para a Bahia escravos, africanos ou crioulos, oriundos de outras províncias. 0 tráfico interno não era 0 dvo da lei como medida de segurança. Desta forma, a legislação deixava evidente que indesejáveis eram os africanos libertos, proibindo até mesmo que estes migrassem da Bahia para outras províncias ${ }^{19}$.

Na medida em que o texto da lei proibia somente a vinda de escravos da África para o Brasil, foi deixada uma brecha para o comércio interno de escravos, podendo ser usada a justificativa de que eles não eram suspeitos de envolvimento no levante. Assim, podemos considerar que os interesses dos traficantes de escravos não foram totalmente prejudicados, até mesmo porque alguns deles eram deputados na época. D epois do levante dos malês era comum que traficantes de escravos utilizassem estratégias para burlar a Justiça e darem continuidade a este tipo de neyócio vendendo cativos para outras províncias. O Rio Grande do Sul era destino de muitos deles. (REIS, 2003, pp.493-495). Considerando tais fatos, as elites baianas encontravam-se numa contradição a respeito da continuidade ou não do tráfico. Ao mesmo tempo em que alguns setores entendiam a importância de repressão ao tráfico de africanos como medida de segurança e como forma de garantir avanços sócioculturais na província, proprietários de escravos e traficantes poderiam até concordar que a presença dos africanos trazia inconvenientes, mas estariam eles dispostos a abrir mão dos seus lucros em nome do "bem" comum?

Fazer com que o tráfico de afircanos não fosse tão prejudicado foi uma das preocupações do deputado José de Cerqueira Lima. Este deputado, que também era traficante de escravos, esteve presente na sessão da Assembléia Legislativa da Bahia em 06 de março de 1835, numa sessão com muitos questionamentos sobre as razões da não reexportação para a África de outros escravos apreendidos depois da Lei de 1831. Cerqueira Lima marcou sua presença nesta sessão requerendo do govemo informações sobre os escravos apreendidos, quantos existiam, causa de morte daqueles que faleceram

${ }^{19}$ APEBA. Assembléia Provincial da Bahia. 05 de maio de 1835. Lei n. 09. Série: Registros de Leis, Livro 1. Eis um trecho do artigo 6: "...na mesma mitaimcomerá onestre, ocapitãoequalquer comandantequepara esta proúmia condvir algum afiicano forro de qualquer sexo quesja uma vez da pudicação da prestete Lè...excetuarão os afícamos não suspaitos queresidremneta proímia enquantonãoseveificar a disposição da segunda partedbartigo4". 
durante a apreensão e o destino dado aos mesmos ${ }^{20}$. Certamente 0 deputado-traficante não estava simplesmente tentando garantir o cumprimento da lei, mas preocupado em evitar que "seus" africanos fossem reexportados ou fossem empregados nas obras públicas, o que lhe causaria enormes prejuízos.

Os artigos da lei número nove que serão comentados adiante legislavam sobre a vida dos africanos na Bahia no que dizia respeito tanto à sua relação com outros africanos, quanto as suas condições de vida. Os artigos seguintes podem ser vistos como uma tentativa de normatizar seu cotidiano impondo-lhes limites que interfeririam de forma significativa nos seus arranjos de vida. No caso dos libertos, estes limites e normas afetavam consideravelmente a sua autonomia e as possibilidades de mobilidade que utilizavam na sua luta diária para (sobre)viver numa sociedade escravista.

O artigo nove da lei número nove funcionou como uma tentativa de fragilizar os laços de solidariedade e cumplicidade entre os africanos, libertos e escravos. Este artigo oferecia diversos benefícios àqueles que denunciassem qualquer plano de insurreição. Dentre estes benefícios, uma vez fosse constatada pela polícia a veracidade da denúncia, estavam a alforria, caso o denunciante fosse escravo. Quando o denunciante fosse forro, a justiça contemplava com a isenção de uma taxa de 10 mil rés que deveria ser paga anualmente ao govemo ${ }^{21}$.

O artigo nove desta lei fez com que a africana liberta Sabina da Cruz fosse recompensada pelos serviços prestados à província da Bahia. Na medida em que deveria pagar uma taxa para mercadejar e pagar uma taxa anual de 10 mil réis atribuída aos libertos africanos, esta liberta foi recompensada pela denúncia que fez do levante, recebendo posteriormente os benefícios oferecidos pela lei. Anos depois, em 1850, Sabina da Cruz enviou uma petição à assembléia provincial legislativa da Bahia esperando ainda contar com os benefícios do seu ato de "fidelidade" ao Estado ${ }^{22}$. Desta vez a liberta Sabina que se apresentou na petição como aquela que “... denumiau a insureçãa de 1835”, pedia para ser dispensada de um novo imposto de 10 mil réis estabelecido desde 1846, dirigido a todos os libertos africanos que mercadejassem. Além da dispensa do imposto, ela pedia o perdão das multas pelo não pagamento da taxa desde a data em que ela entrou em vigor. Sabina da Cruz recebeu no mesmo ano o resultado positivo da sua solicitação. 0 texto em que a lei

${ }^{20}$ APEBA. Ata das Sessões da Assembléia Provincial Legislativa do ano de 1835. Sessão de 06 de março. Livro 206.

${ }^{21}$ APE BA. Assembléia Provincial Legislativa da Bahia. 05 de maio de 1835. Lei número 9. Série: Registro de Leis, livro 1-2.

22 APEBA. Seção Legislativa, pareceres de 1848 até 1850, livro 143. 
foi publicada no ano de 1850 dava ênfase ao fato de que 0 imposto de 10 mil réis "comprendeuricameteas pretas epreos aficanos". Ficou também registrado no texto legal que a referida liberta estava isenta do imposto, bem como das multas retroativas ${ }^{23}$.

Um outro artigo que compunha esta lei, o artigo dezessete, fez da decisão de continuar vivendo na Bahia uma "escolha" difícil. Este artigo proibia os africanos libertos de possuírem "bens de raiz" (imóveis), além de anular os contratos firmados com eles, mesmo se anteriores a esta Lei. Este artigo era seguido do artigo dezoito que proibia que proprietários alugassem seus imóveis a escravos e africanos libertos, a menos que estes possuíssem autorização do juiz local ${ }^{24}$. Desta forma, até mesmo os acordos firmados entre senhores e cativos que garantissem, por exemplo, que o escravo vivesse "por si", passaram a sofrer interferência da Justiça. Pensando os resultados desta lei sobre a vida dos africanos libertos, podemos citar as atividades desempenhadas por este grupo na cidade de Salvador no século XIX. Ser liberto na Bahia do século XIX significava viver sobre si, ou seja, garantir sua manutenção, principalmente no que diz respeito à moradia e alimentação. Alguns libertos conseguiram adquirir bens, e para fugir das proibições deste artigo, alguns passaram seus imóveis para o nome de terceiros (O LIVEIRA, p.40).

Por fim, o artigo dezenove também interferia nas relações entre cativos e senhores atribuindo a estes últimos a obrigação de batizarem seus escravos africanos "boçais" na religião católica. Percebemos aqui que a repressão aos malês foi também de ordem cultural. Como já dissemos os senhores baianos sabiam que a religião muçulmana era fator agregador e organizador da comunidade africana. Tornar-se católico também pressupunha estar de acordo com as "normas" para viver nesta sociedade. Ser católico também era utilizado como argumento no momento em que era preciso mostrar que se estava quite com a justiça, no caso de em algum momento fosse considerado suspeito de ações contra a escravidão e, por conseqüência, contra o Império.

A ameaça africana não permeava somente 0 imaginário dos legisladores baianos e proprietários de escravos. Diversos setores da população, inclusive crioulos escravos e libertos, em momentos em que fosse necessário, também poderiam afirmar que os africanos eram um perigo para sua integridade. Ainda assim, podemos imaginar que, de alguma forma, a dura perseguição aos africanos também incidiu sobre eles. Por isso, para os crioulos, destacar-se dos africanos era significativo em alguma medida, sobretudo

${ }^{23}$ Coleção das Leis e Resoluções da Assembléia Legislativa Provincial da Bahia nos anos de 1850-1852. Typ. Constitucional de França Guerra. 1865.

${ }^{24}$ APE BA. A ssembléia Provincial Legislativa da Bahia. 05 de maio de 1835. Lei número 9. Série: Registro de Leis, livro 1-2. 
quando tinham como altemativa se inserir numa sociedade em que, o fato de ser negro era facilmente associado à origem africana. Isto explica o fato de que um setor mais pobre da população composto por "não-brancos", fizesse coro às exigências da elite baiana por mais segurança, por entender que os africanos traziam perigos para eles também.

Como exemplo deste fato, temos um parecer que chegou à Assembléia Provincial Legislativa da Bahia em 06 de junho de 1835. Através deste documento, a viúva Maria da Graça pedia uma pensão à Justiça para seu sustento e dos seus dois filhos menores. Segundo ela, seu marido, Joaquim dos Reis Maciel, pardo, alfaiate, trabalhava como guarda dos trapiches como forma de complementar a renda da família, na noite do levante dos malês. Segundo a viúva, Joaquim fora "barbaramente assassinado pelos insurgidos africanos na noite de 25 de janeiro", quando regressava para casa ${ }^{25}$. 0 procurador de Maria da Graça, José João Cardoso, tilizou-se de fortes argumentos que sensibilizassem e convencessem os deputados baianos a aprovarem a concessão de uma pensão para viúva, que se encontrava grávida de oito meses. Após ser atestada sua pobreza, ela conseguiu a pensão solicitada.

Este episódio pode ser intepretado como indício da mentaldade baiana das primeiras décadas do século XIX, que via nos africanos uma ameaça concreta à integridade das pessoas de bem, atingindo inclusive os "não-brancos". Esta espécie de "propaganda anti-africana" que tomava conta da cidade de Salvador, mostrava que, segundo 0 imaginário coletivo, todos os segmentos sociais corriam riscos diante do caráter indócil e bárbaro dos africanos. Este temor fez com que os setores mais privilegiados da sociedade baiana iniciassem um movimento de reivindicações às autoridades visando implementar medidas repressivas à população africana.

Situações como a que ocorreu ๓n março de 1835 corroboram com nossa argumentação. No dia 24 daquele mês, um grupo de proprietários de escravos enviou um abaixo-assinado composto por mais de 300 assinaturas à Assembléia Legislativa. Assinavam o documento cidadãos que podeniam, por exemplo, assumir cargos públicos ou políticos devido à sua posição social. Entre os assinantes estão funcionários públicos, médicos, policiais, juristas, lavradores, proprietários e negociantes, ou seja, ocupações que tinham certa capacidade de mobilização e influência política ${ }^{26}$.

${ }^{25}$ APEBA. A ssembléia Provincial e Legislativa da Bahia. Pareceres. Livro 137. 06.06.1835.

${ }^{26}$ APEBA. Sessão Legislativa, série Abaixo Assinados. Livro 979. 1835. 
A leitura deste documento nos revela muito das impressões deste segmento social a respeito do que significavam a presença dos africanos na sociedade. Logo, o abaixoassinado é um bom indicativo do pensamento daqueles que o assinaram. 0 documento começa expondo a crença de que o tráfico de escravos era o fator responsável pelo levante na medida em que trazia muitos africanos para a província. 0 tráfico era entendido como um mal que trazia ameaça para a nação, pois tornava real a possibilidade de que uma nova insurreição africana pudesse ocorrer. A solução sugerida (ou exigida) por estes senhores, além do fim do tráfico era a exportação dos africanos livres. Os assinantes fazem a ligação entre a presença dos africanos e o perigo que traziam para a sociedade. Os senhores que construíram 0 argumento do abaixo-assinado revelam sua percepção da interação entre africanos libertos e escravos. Assim, acreditavam que os africanos libertos eram perigosos e deveriam ser deportados pelo seguinte:

São estes, excelentíssimo senhor, o mais seguro apoio para as conspirações dos escravos, outrora seus parceiros quando já da liberdade. Mas sabendo melhor ajuizar da dureza da escravidão e por isso sabem melhor descrever os ainda escravos das delícias daquela27.

Os africanos libertos ainda eram acusados de fornecer armas, dinheiro, além de se organizarem em tomo de escolæs e associações. Assim sendo, aqueles que antes foram utilizados como fonte de renda e riqueza da elite baiana, já não eram mais bem vindos em nome da segurança da província Os africanos também eram acısados de serem responsáveis pela destruição social e política do Brasil. Podemos pensar o que queria dizer esta afirmação. É possível que neste ponto, estivessem se referindo não somente às revoltas, como também à imposição de uma cultura afro-baiana que fugia aos propósitos de europeização corrente em todo país.

Recorrendo ao pensamento liberal brasileiro que tinha por caracteństica particular e contradição o convívio com a escravidão, os autores do documento justificam suas medidas da seguinte forma:

Uma tal medida por ser de salvação pública, não implica de forma alguma com 0 direito das gentes, não só porque com os africanos não tem o Brasil espécie de tratado ou convenção, como porque eles não representam no mundo político e civilizado...28.

${ }^{27}$ APEBA. Sessão Legislativa, série Abaixo Assinados. Livro 979. 1835.

28 APEBA. Sessão Legislativa, série Abaixo Assinados. Livro 979. 1835. 
Este excerto revela mais sobre o caráter contraditório do pensamento da elite liberal brasileira. Os assinantes do documento reconheciam a capacidade de organização dos africanos, mesmo acreditando que eles fossem social e juridicamente inferiores. Aqui, a humanidade e a cidadania apareciam como algo restrito aos brancos, únicos que faziam parte do mundo civilizado, o que excluía os africanos. Em resumo, acreditavam que capacidade de organização dos africanos existia, mas era penigosa já que era dotada de caráter bárbaro.

O utro aspecto que podemos inferir a partir deste excerto, era sobre o caráter jurídico dos africanos libertos. Segundo Grinberg, a cidade de Salvador na primeira metade do século XIX, assim como outras grandes cidades da América, era um ambiente propício para possíveis estratégias de mobilidade social dos libertos Esta possibilidade de mobilidade social não era bem vista aos olhos de boa parte de políticos e parlamentares (GRINBERG, 2002, p.56). Se para alguns era consenso a impossibilidade de africanos libertos serem cidadãos, para outros, isto era uma questão ainda a ser debatida. A opinião do deputado Antônio Rebouças, era dissonante entre seus colegas. Para Rebouças, era incontestável a não-cidadania dos africanos escravos, porém, uma vez libertos, estavam aptos a receber status jurídico de cidadãos.

Q uando aqueles que assinam o abaixo assinado de 24 de março de 1835 afirmam que "tal medida por ser desalvaçãopúlica, não implica deforma alguma como dreito das gentes", queriam dizer que tais medidas não iam contra direitos de cidadania, visto que os libertos africanos não eram cidadãos. Desta forma, em nome da segurança, acreditavam que era legítimo que os libertos fossem deportados do Brasil para "qualquer parte" do continente africano. Isto revela que para os senhores do abaixo-assinado, os africanos que viviam na Bahia em 1835 e que vinham de diversas partes do continente africano, poderiam agora ser "devolvidos" para seu lugar (único) de origem, uma vez que naquele momento eram indesejáveis. As petições escritas por alguns destes africanos, nas quais reivindicam o direito de voltar para a Bahia, mostram que esta questão não se esgotou num debate entre pares.

\section{Conclusão}

Como podemos perceber os africanos não imprimiram sua presença na Província da Bahia somente como mão-de-obra dos plantéis ou como parte das centenas de africanos que desenvolviam atividades comerciais na cidade de Salvador e do recôncavo. 
Aos olhos da Justiça e dos senhores de escravos, eles também significavam uma questão de segurança que carecia de medidas legais específicas, mas que não eram tratadas com a devida especificidade pelo governo Imperial e Provincial. Assim, pela observação das leis produzidas na Província da Bahia, podemos perceber como políticos e proprietários de escravos achavam que deveriam tratar com atenção particular o "problema africano". Além disso, observando as leis provinciais, também podemos entender os valores que conduziam as ações do grupo que compunha a elite baiana.

A questão africana não foi uma questão que "assustava" somente a Bahia. As notícias sobre o levante dos malês tomaram todo o Brasil. Os historiadores Flávio dos Santos Gomes e Carlos Eugênio Líbano Soares apontam a existência de uma associação entre cultura, religiosidade e resistência que uniu africanos de diversos grupos étnicos no Rio de Janeiro ${ }^{29}$. Estes historiadores ainda acreditam que o medo das elites brasileiras tinha cor e etnia A notícia do levante dos malês fez surgir o "fantasma" de uma insurreição que tomasse todo o Brasil, devido ao grau de organização dentro do grupo africano. Isto fez com que a legislação sobre os africanos se tomasse mais sofisticada em termos de controle social depois do levante de 1835. Chamando atenção para a legislação apresentada neste trabalho, que obrigava o uso de passaportes aos africanos desde 1830, e fazendo uma associação com a ocorrência de outras revoltas escravas na Bahia desde o iníáo do século XIX, podemos acreditar que a vigilância dos africanos já era uma preocupação das autoridades policiais e políticas na província antes de 1835.

Como é mostrado por Gomes e Soares, o Rio de Janeiro também tomou medidas para conter os aficamos mina que chegavam pelo tráfico interno de escravos. Da mesma forma que na Bahia, a presença dos libertos africanos também não era desejada no Rio de Janeiro, e o debate sobre o cumprimento da lei de 1831 acabou virando pauta principal nas discussões sobre as causas que colaboraram com a organização dos africanos e ocorrência de revoltas. Na Bahia, pelo menos até 1835, os olhos da polícia e da Justiça não estavam voltados para um determinado grupo étnico africano específico, como acontecia no Rio de Janeiro em relação aos africanos de nação mina. Embora soubessem que os escravos envolvidos no levante dos malês eram em sua maioria haussás e nagôs, a religião muçulmana foi sinônimo de escravo perigoso, além da nacionalidade africana de maneira genérica.

${ }^{29}$ GO ME S, Flávio e SOARES, Carlos Eugênio Líbano Soares. "Comos Pés sdreumVuicãa Africanos Minas, Identidades eRepressãoanti-africananoRiodeJaniro(1830-1840). Estudos Afro-A siáticos, ano23, no. 02, 2001. 
Pode-se inferir que as leis baianas sobre africanos expressavam o pensamento de uma elite sobre 0 modo de vida e $\$$ práticas dos africanos que poderiam pôr em risco e fragilizar a estrutura social. A partir desta crença, foram pensados variados mecanismos jurídicos para reprimir os grupos "perigosos" e administrar a contradição entre a necessidade de mão de obra e o medo de revoltas. De forma imdireta, estes africanos também deixaram presente nas leis e debates políticos as suas ações, práticas religiosas e valores culturais, além dos arranjos que faziam na Bahia.

\section{Bibliografia:}

1. AZEVED O, Celia Maria Marinho de. Onda nega, meebbranca O nego mimaginániodas ditessédoXIX. Rio de Janeiro, Paz e Terra, 1987.

2. CHALHOUB, Sidney. Visões da Libedade Uma históia das últimas déadas da exravidăo ma Cate São Paulo, Cia das Letras, 1990.

3. GRINBERG, Keila. O Fiadr dos Brasileros Cidadania exravidăo e dirito àil mo tempo de AntôiioPerira Rebaŗ̧as Rio de Janeiro, Civilização Brasileira, 2002.

4. KARA SCH, Mary. A vida des Escravosmo RiodeJaniro São Paulo, Cia das Letras, 2000.

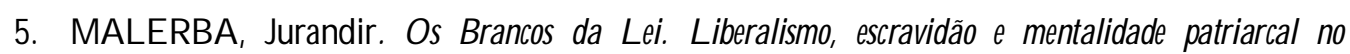
Impéio Maringá: E ditora Universidade de Maringá, 1994.

6. OLIVEIRA, Maria Inês Côrtes de. O Libata saummoeos atros Salvador, 1790/ 1890. São Paulo, Editora Corrupio, 1988.

7. REIS, João José e GOMES, Flávio dos Santos (orgs). Libardade por um fia históia de quilombos noBrasil. São Paulo, Cia das Letras, 1996.

8. REIS, João José e SILVA, Eduardo. NegciaçãoeConflita A resistênia nega mo Brasil exravista São Paulo, Cia das Letras, 1989.

9. Rebdião Escrava m Brasil. Histáia do Leante des Malês em 1835. Edição revista e ampliada. São Paulo, Companhia das Letras, 2003.

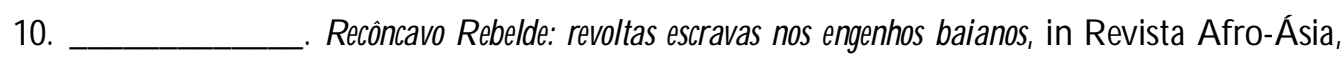
SSA: CEAO/UFBA, n 15, 1992, pp 104.

11. WISSENBACH, Maria Cristina Cortez. Sarhos Afiicanos, viênias ladinas exavos efornos em São Paulo(1850-1880). São Paulo: HUCITEC, 1998. 